\title{
Second victims, organizational resilience and the role of hospital administration
}

\author{
Chiara M Santomauro", Cor J Kalkman², Sidney WA Dekker ${ }^{3}$ \\ 1. The University of Queensland, Australia. 2. Division of Anesthesiology, Intensive Care and Emergency Medicine, \\ University Medical Center Utrecht, Netherlands. 3. Safety Science Innovation Lab, Griffith University, Australia. \\ Correspondence: Chiara Margherita Santomauro. Address: The University of Queensland, Australia. E-mail: \\ c.santomauro@uq.edu.au
}

Received: March 2, 2014

Accepted: April 4, 2014

Online Published: April 28, 2014

DOI : $10.5430 /$ jha.v3n5p95

URL: http://dx.doi.org/10.5430/jha.v3n5p95

\begin{abstract}
Second victims are practitioners involved in an incident that (potentially) harms or kills somebody else, and for which they feel personally responsible. Professional culture and the psychology of blame (and shame) influence how second victims are viewed and dealt with. This paper reviews the status of second victimhood in healthcare - both its symptomatology and organizational responses. Then it considers the problematic nature of "human error" in healthcare and sets this against the psychological backdrop of healthcare professions, seeking cultural-historical explanations in assumptions of actor autonomy and professional identity. It concludes by drawing links between the psychological resilience of the individual practitioners involved in an incident and the resilience of an organization's safety culture.
\end{abstract}

\section{Key words}

Blame, Error, Second victim, Healthcare, Organizational culture, Resilience

\section{I ntroduction}

In 2010, a pediatric patient died at Seattle Children's Hospital from a calcium chloride overdose. The nurse, Kimberley Hiatt, was escorted off the premises, suspended, then fired, and her license to practice was re-instated only with onerous and humiliating conditions. Her health and psychological well-being deteriorated, and she never found work as a nurse again, even though the death of the infant could later not clearly be linked to her actions ${ }^{[1]}$. Aged fifty, Hiatt, "a healer at heart" according to friends and family, had lost a patient, a job and an identity. She committed suicide seven months after the child's death ${ }^{[2]}$.

For those whose research spans different safety-critical domains - healthcare, nuclear power, aviation, rail, chemical process control - one of the most vexing questions is what accounts for the large differences in their safety performance ${ }^{[3-5]}$. While some may consider the structural properties of systems that do safety critical work ${ }^{[6]}$, many rely on organizational safety culture to carry the explanation of differences in safety performance. They refer, for example, to relationships between leaders and followers, managerial openness to dissent and inquiry, group-versus individual orientation, the extent of bureaucratization of safety, assumptions of personal invulnerability, and values regarding rules and procedures ${ }^{[7-11]}$. 
Another co-variant with safety performance, which is increasingly recognized ${ }^{[12-14]}$, is an organization's attributional inclination when things go wrong. What or whom might they blame, and what do they do with those involved in incidents? The psychological literature has previously shown links between culture and attributional style ${ }^{[15]}$, which could well extend to a professional or organizational culture.

There is a likely correlation between the psychological resilience of an individual involved in a mishap ${ }^{[16,17]}$ and the resilience of the organization as a whole ${ }^{[18]}$. A professional community that acknowledges its error-proneness is more likely to put safety processes in place to protect against them, while also supporting those who become the instantiations of such imperfection ${ }^{[19]}$. Healthcare has most extensively documented the plight of its second victims, yet has paradoxically not invested proportionally in organizational support (unlike emergency response, for example, including fire-fighting and police ${ }^{[20]}$, or air traffic control ${ }^{[21]}$ ). Reporting a mistake can be seen as jeopardizing one's employment or career ${ }^{[22]}$ and seeking support can be stigmatized as a weakness ${ }^{[23]}$. Whereas quantitative comparison across domains is not possible for lack of data, studies in healthcare present second victimhood as very prevalent, from one in ten practitioners ${ }^{[24]}$, to $30 \%{ }^{[25]}$, to over $40 \%{ }^{[23]}$. Healthcare is also seen by many in safety as an "outlier" for its complexity as well as the special organizational and societal status of many of its practitioners ${ }^{[26,27]}$. Few other safety-critical domains have retained the actor autonomy and craftsman mindset of many medical specialties, in which professionals with equal positions are not viewed as equivalent. Systematization of practice and assumptions of actor equivalence reign in several domains, from commercial aviation to nuclear power, but are relatively new in healthcare ${ }^{[28-30]}$.

In addition, the complexity of the system that delivers both success and failure ${ }^{[31,32]}$, and how disease and patient characteristics mix with medical intervention, all help create an ambiguous and contested causal landscape ${ }^{[27,33,34]}$. There is no field that relies simultaneously on personal achievement to explain its successes and on individual shortcomings to explain its failures as much as healthcare does ${ }^{[35]}$. Personal blame can travel easily and nestle more comfortably in a complex, ambiguous landscape, as can self-serving attributions for good outcomes ${ }^{[36,37]}$. This is compounded by the fact that healthcare has generally resisted the kind of sector-based, immediate, technically competent and independent adverse event investigations that are legally required in many other fields ${ }^{[32,38,39]}$.

The complexity and diversity of healthcare delivery make any broad statements about its "organizational culture" suspect ${ }^{[40]}$, yet there is consistency in the medical and safety literature about how failure and success are given meaning and handled ${ }^{[41-43]}$. Cultures that assume perfection, in which errors are not tolerated and personal responsibility of one's actions (both error and outcome) is expected, are still common ${ }^{[44]}$.

In this paper we review the status of second victimhood in healthcare - both its symptomatology and organizational responses - for hospital administrators to consider whether there are links between professional culture, the psychology of blame and organizational resilience at their own facilities. We first consider the problematic nature of "human error" in healthcare and set this against the psychological backdrop of healthcare professions, briefly looking at cultural-historical assumptions about actor autonomy and professional identity. We then aim to draw a link between the psychological resilience of the individual practitioners involved in an incident and the resilience of an organization's safety culture.

\section{Second victims}

Second victims are practitioners involved in an unanticipated incident that (potentially) harms or kills somebody else, to which the practitioner is traumatized by the event and feels personally responsible ${ }^{[23]}$. Different prevalence rates of second victimhood exist (see Tables 1-2), but as Wu reported, almost every practitioner knows the "sickening realization" of making an error ${ }^{[45]}$. Regardless of gender, professional type, or years of experience, becoming a second victim was determined to be a life-altering event that left a permanent imprint on most individuals, yet fewer than one out of three second victims received institutional support to deal with this stress ${ }^{[23]}$. A recent study found even fewer (one in four) healthcare workers received organizational support following an adverse event, and this lack of support lengthened and exacerbated the negative impact of the event ${ }^{[46]}$. 
Table 1. Prevalence of second victimhood in healthcare

\begin{tabular}{lll}
\hline Group Surveyed & Percentage of Group Surveyed & Description \\
\hline $\begin{array}{l}\text { Healthcare employees }(e . g . \\
\text { nurses, physicians, pharmacists) }\end{array}$ & $60 \%^{[47]}$ & $\begin{array}{l}\text { Could recall an adverse event in which they were a second } \\
\text { victim }\end{array}$ \\
$\begin{array}{l}\text { Healthcare employees }(\text { e.g. } \\
\text { nurses, physicians, pharmacists) }\end{array}$ & $46 \%^{[47]}$ & $\begin{array}{l}\text { Described being a second victim when recounting a serious } \\
\text { adverse event }\end{array}$ \\
Hospital house staff & $47 \%^{[48]}$ & $\begin{array}{l}\text { Described one or more errors that they had committed and } \\
\text { demonstrated various coping and defense mechanisms to } \\
\text { deal with these errors }\end{array}$ \\
\hline
\end{tabular}

Table 2. Prevalence of suicidal ideation and negative impacts in healthcare

\begin{tabular}{lll}
\hline Group Surveyed & Percentage of Group Surveyed & Description \\
\hline Surgeons & $\begin{array}{l}5.4 \% \text { (a threefold increase (16.2\%) } \\
\text { was observed if the medical error was } \\
\text { made in the past three months) }\end{array}$ & $\begin{array}{l}\text { Reported suicidal ideations after } \\
\text { making a major medical error in the } \\
\text { previous } 12 \text { months }\end{array}$ \\
$\begin{array}{l}\text { Physicians who had experienced a patient that } \\
\text { had been seriously injured due to the treatment } \\
\text { they administered (either a few times or several) }\end{array}$ & $17 \%^{[50]}$ & $\begin{array}{l}\text { Indicated a negative impact on their } \\
\text { private life }\end{array}$ \\
\hline
\end{tabular}

Christensen, Levinson and Dunn ${ }^{[51]}$ found how medical mistake causes distress, agony and anguish, fear, guilt, anger, embarrassment, humiliation, depression, concern for patient or family wellbeing and possible litigation, and trepidation about the reaction of colleagues ${ }^{[51]}$. The willingness to share their distress was influenced by how competitive they perceived their relationship with co-workers to be. Christensen and colleagues noted the general absence of a concept of “fallibility" particularly in physician training and culture ${ }^{[52]}$. The depth of a physician's distress was mitigated by prior beliefs in their infallibility and their commitment to perfectionism. Strong beliefs lead them to maintain the illusion of perfection; to see mistakes as impossible and virtually unforgivable moral failings ${ }^{[51]}$.

Surveys of healthcare providers involved in fatal medication errors confirmed the effects of a culture of perfection ${ }^{[44]}$, revealing fear of humiliation, public scrutiny, litigation, disciplinary action and punishment, and the hiding of errors or blaming of others where possible. Shame, guilt, depression, an unanswered need for support as well as the (sometimes hopeless) hope to correct the wrong were all emotions and feelings shared by second victims ${ }^{[25]}$. Drawn-out inquiries into the medication error and a lack of organizational understanding tend to exacerbate the trauma. As a result, reporting of medication errors was generally avoided for fear of repercussions, and support by peers who had similar experiences was hard to come by ${ }^{[22]}$. Healthcare professionals generally punish themselves quite harshly in the wake of failure and the memory typically stays with them for years ${ }^{[51]}$. A strong coping strategy, however, was having the opportunity to informally discuss errors with colleagues ${ }^{[53]}$. Yet the desire for support and counseling was offset by a fear of stigmatization in a recent large-scale study ${ }^{[54]}$.

Attributions of medical errors:

“Attributing situations to 'others' in a perceived causation, at the conclusion of complex events, produces relatively quick, easy, and efficient solutions. This process is historically preferred and often advocated in healthcare management” [55].

When errors cannot be denied, novice physicians defend themselves by externalizing the blame to someone/something other than themselves. This includes blaming superiors, subordinates, or colleagues within medicine, disease, and the patient ${ }^{[48]}$.

When interviewed about medical errors they had made in the past, 35\% of healthcare providers felt anger/frustration and blame most often directed at other healthcare providers ${ }^{[56]}$. 


\section{Blame and the impossibility of medical mistake}

Society tends to see in physicians an image of perfection ${ }^{[26]}$, so a physician might have to suffer the consequences of mistake in silence ${ }^{[57]}$. One out of three physicians who had been involved in at least one adverse clinical event (where the patient was seriously injured) felt they had been blamed by the patient or patient's family afterwards ${ }^{[50]}$. Mistakes are recognized as inevitable, yet the standard of medical practice is to yield perfection. This paradox can produce shame about mistake - an emotion concerned not just with one action or omission, but with the entire self ${ }^{[58,59]}$. This tends to interfere with the ability to show empathy to the self or patients ${ }^{[53]}$, or to seek it from colleagues ${ }^{[45]}$. Leape ${ }^{[57]}$ attributed the difficulty physicians have in dealing with human error to the medical culture: the notion that mistakes are unacceptable leads to the unrealistic expectation of infallibility. Thus, when an error occurs, it is attributed to a failure of character.

Table 3 presents research on shame, self-blame, and other side effects following a medical error, and these feelings tend to be exacerbated when the error leads to a worse outcome. When nurses were asked to imagine themselves making an error that either resulted in a serious outcome or a non-serious outcome, nurses reported more self-blame in the serious outcome condition, compared to the non-serious outcome condition. However, all nurses tended to blame themselves regardless of the outcome ${ }^{[64]}$. In addition, when being interviewed about medical errors, residents repeatedly expressed that the nature of their emotional response was strongly affected by both the patient outcome and the extent of personal responsibility for the mishap. More intense reactions were reported for mishaps associated with poor patient outcomes and higher levels of personal responsibility ${ }^{[56]}$. Judgments of responsibility (that is, blame) are also associated with outcome. This finding supports early research claiming that the consequences of an action affect the attributions of responsibility for that action ${ }^{[65]}$.

Table 3. Emotional side effects of making a medical error

\begin{tabular}{|c|c|}
\hline Item & Description \\
\hline \multirow[t]{2}{*}{ Shame } & $\begin{array}{l}75 \% \text { of those who had made a medical mistake that had the potential to harm a patient felt ashamed of making an } \\
\text { error in front of the operating room staff }{ }^{[60]} \text {. }\end{array}$ \\
\hline & $54 \%$ of physicians asked to recall their worst error reported feeling shame ${ }^{[61]}$. \\
\hline \multirow{3}{*}{ Self-blame } & $\begin{array}{l}\text { When asked about the death of patients due to a medical error, physicians' self-blame extended well beyond } \\
\text { admitting to minor errors. They may feel they have caused the death of patients }{ }^{[62]} \text {. }\end{array}$ \\
\hline & $86 \%$ of physicians asked to recall their worst error reported feeling self-blame ${ }^{[61]}$. \\
\hline & Nurses internalized blame as they accounted for their actions after a medical error ${ }^{[63]}$. \\
\hline Loss of sleep & $\begin{array}{l}\text { Respondents who scored higher on error-related questions (such as "I have made mistakes that had the potential to } \\
\text { harm patients") were more likely to lose sleep from their concerns of patient welfare }{ }^{[60]} \text {. }\end{array}$ \\
\hline \multirow[t]{2}{*}{ Self-doubt } & $\begin{array}{l}\text { More than one third of physicians experienced guilt, self-doubt and feelings of intense personal responsibility after } \\
\text { a medical error }{ }^{[56]} \text {. }\end{array}$ \\
\hline & $96 \%$ of physicians asked to recall their worst error reported feeling self-doubt ${ }^{[61]}$. \\
\hline
\end{tabular}

Striving for perfection is consistent with the idea of medicine as a vocation ${ }^{[30]}$ rather than technical work or contract-based profession. Errors are regarded as non-existent anomalies in the medical system. In fact, one third of intensive care staff refuses to acknowledge they make any mistakes ${ }^{[66]}$. This makes errors, in principle, not reportable and sources of shame. In his study of surgical trainees, Bosk ${ }^{[42]}$ found that colleagues and superiors tend to classify errors as blameless and blameworthy. The safety literature generally recommends the development of strategies for open reporting of errors in order to help reduce the stigma and shame that are likely to accompany them.

\section{Autonomy and professional identity}

Healthcare has a unique and complex relationship to the autonomy and discretion of its individual actors. Individual human virtue is seen as the basis for safety; and human incompetence as the source of risk ${ }^{[67]}$. This simultaneous belief in human strength and weakness sets healthcare apart from most other safety-critical worlds where error and expertise are 
seen as the joint product of system and individual ${ }^{[68]}$. The culture of autonomous, responsible actors in healthcare lags, in a sense, behind the evolution in the West from so-called status-determined duties to contractual or commerciallydetermined duties ${ }^{[26]}$. In a status-determined social relationship, members of society derive professional rights, duties and liabilities from their calling or status. Pre-historical and contemporary accounts of healers ${ }^{[69-73]}$ stress their unique cultural position. Modern healthcare can be seen as a calling to a duty outside of normal, secular contractual obligations: a profession of healing and helping ${ }^{[74,75]}$. As modernization and industrialization spread across professions in the West, particularly during the nineteenth century, physicians resisted the notion that their relationship with patients was like a commercial or contractual one, even if they were the ones paying for the service ${ }^{[26]}$. The doctor's duties to heal were not based on a contract (or the fact that money exchanged hands) but on calling and status.

It was one important reason for the development of tort law: The special doctor-patient relationship was different from other commercial agreements. Medical malpractice was (and still is) not asserted for breach of contract, but rather for the professional not doing what they were supposed to do ${ }^{[26,31]}$. Parts of the "mythic nobility" (p. 2) of medical competence are reproduced structurally today ${ }^{[76]}$. This includes super-human working hours even though patients do measurably worse when nurses work shifts longer than 12 hours ${ }^{[77]}$, and intensive care unit residents make fewer errors when they work shifts averaging 16 hours instead of 36 hours ${ }^{[78]}$. Two thirds of medical staff deny the effects of fatigue on performance, compared to less than a third of pilots ${ }^{[66]}$, and attempts to regulate working hours can run up against cultural limits.

Other examples include the lag in systematic use of usability techniques and ergonomic principles in healthcare technology ${ }^{[79-81]}$. There are few avenues to report design or usability problems once technology is fielded, and there may be attraction in heroic acts and creative workarounds necessary to make technology work ${ }^{[82]}$. The healthcare system also accepts deviations from protocol, guidelines or any other standard - as long as these emanate from its senior or higherstatus practitioners. Hand-written prescriptions still survive ${ }^{[83]}$ and lead to far more prescription and medication errors then get reported. Such errors seem to be accepted as a natural part of practice ${ }^{[84]}$.

\section{Second victimhood, blame and organizational resilience}

Progress on dealing with second victims in healthcare has been slow compared to other safety-critical worlds such as emergency response (police, fire-fighting) and aviation ${ }^{[20,85,86]}$. In these worlds, actor autonomy has been constrained as compared to certain areas of healthcare. Working hours are strictly regulated, standardization and procedures are expected and common. Error tends to be acknowledged as an undesirable but inevitable by-product of the pursuit of success under uncertainty and limited resources ${ }^{[68]}$. Error and the potential for outcome failure is seen as manageable, its existence is acknowledged, and its links to context rather than person can be made explicit. This has inspired systems to manage safety by identifying organizational error traps and other vulnerabilities and limiting their consequences, but also institutional responses to the second victims of error ${ }^{[87]}$. All air traffic control organizations across Europe today, for instance, are expected to have extensive critical incident and stress management programs ${ }^{[21]}$, designed to help people affected by incidents to recover to normal functioning and behavior. Well-supported employees return to normal duties more quickly following an incident ${ }^{[85]}$.

The resilience of a practitioner is a joint product of environment and individual characteristics - but the role of community, of social support, is central. There are likely strong links between the resilience of a practitioner in the wake of failure, and resilience of an organization ${ }^{[88,89]}$. It is the authors' opinion that by dismissing a second victim, an organization signals fear, denial, liability concerns, and cuts off a voice in understanding what makes its operations strong or brittle. In contrast, embracing the existence of second victims, taking responsibility for them and helping them become resilient in the face of possible trauma will help the organization become more resilient as well. 
One example is the attention to the second victim in the "seven pillars" program from the University of Illinois Medical Center at Chicago ${ }^{[90]}$. This approach is designed for hospital administrators to promote the adoption of transparency following a medical error in order to improve both patient and practitioner outcomes. The "seven pillars" correspond to seven steps to guide responses to an adverse event: patient safety incident reporting, investigation, communication and disclosure (with the patient and their family), apology and remediation, system improvement, data tracking and performance evaluation, and education and training. Implementing the "seven pillars" program or similar programs aimed at increasing transparency will inevitably motivate the organization to try to learn from things that went wrong, and prevent them from happening again.

Some healthcare organizations might still deal with second victims as if they are the surprising, unpredictable collateral damage of morally repugnant events. One may wonder if such hospitals are sufficiently calibrated about the safety-critical processes they manage, and their ethical implications. Society once endowed the practitioner - now a second victim - with the responsibility for a unique relationship of trust, a fiduciary relationship, with the first victim: the patient. By paying off the first victim and sending off the second the organization denies the humanity and reality of the relationship that existed between the two victims. Yet it is this very relationship that the organization counts on for its continued existence, and the very relationship that helped give rise to the professional culture in the first place.

\section{Competing interests}

The authors declare that they have no competing interests.

\section{References}

[1] Newland J. Medical errors snare more than one victim. The Nurse Practitioner. 2011; 9: 1.

[2] Ostrom CM. Nurse's suicide follows tragedy. The Seattle Times. 21 April 2011. Local News.

[3] Amalberti R. The paradoxes of almost totally safe transportation systems. Safety Science. 2001; 37(2-3): 109-126. http://dx.doi.org/10.1016/S0925-7535(00)00045-X

[4] Rochlin GI. Safe operation as a social construct. Ergonomics. 1999; 42(11): 1549-1560. http://dx.doi.org/10.1080/001401399184884

[5] Rasmussen J. Risk management in a dynamic society: A modelling problem. Safety Science. 1997; 27(2-3): 183-213. http://dx.doi.org/10.1016/S0925-7535(97)00052-0

[6] Perrow C. Normal accidents: Living with high-risk technologies. New York: Basic Books. 1984.

[7] Antonsen S. Safety culture and the issue of power. Safety Science. 2009; 47(2): 183-191. http://dx.doi.org/10.1016/j.ssci.2008.02.004

[8] Helmreich RL. Culture and error in space: implications from analog environments. Aviat Space Environ Med. Sep 2000; 71(9 Suppl): A133-139. PMid: 10993326.

[9] Silbey S. Taming Prometheus: Talk about safety and culture. Annual Review of Sociology. 2009; 35: 341-369. http://dx.doi.org/10.1146/annurev.soc.34.040507.134707

[10] Johnston AN. CRM: Cross-cultural perspectives. In: Wiener EL, Kanki BG, Helmreich RL, eds. Cockpit resource management. San Diego: Academic Press. 1993; 367-398.

[11] Vaughan D. The dark side of organizations: Mistake, misconduct, and disaster. Annual Review of Sociology. 1999; 25: 271-305. http://dx.doi.org/10.1146/annurev.soc.25.1.271

[12] Reason JT. Are we casting the net too widely in our search for the factors contributing to errors and accidents? In: Misumi J, Wilpert B, Miller R, eds. Nuclear safety: A human factors perspective. London: Taylor \& Francis. 1999; $210-223$.

[13] Dekker SWA. Just culture: Who draws the line? Cognition, Technology \& Work. 2009; 11(3): 177-185. http://dx.doi.org/10.1007/s10111-008-0110-7

[14] Patankar MS, Brown JP, Treadwell MD. Safety ethics: Cases from aviation, healthcare, and occupational and environmental health. Aldershot, England; Burlington, VT: Ashgate. 2005.

[15] Choi L, Nisbett RE, Noenzayan A. Causal attribution across cultures: Variation and universality. Psychological Bulletin. 1999; 125: 47-63. http://dx.doi.org/10.1037/0033-2909.125.1.47 
[16] Kroll J. Posttraumatic symptoms and the complexity of responses to trauma. JAMA. 2002; 290(5): 667-670. PMid: 12902373. http://dx.doi.org/10.1001/jama.290.5.667

[17] Scaer RC. The trauma spectrum: Hidden wounds and human resiliency. New York: Norton. 2005.

[18] Hollnagel E, Nemeth CP, Dekker SWA. Resilience Engineering: Remaining sensitive to the possibility of failure. Aldershot, UK: Ashgate Publishing Co. 2008.

[19] Weick KE, Sutcliffe KM. Managing the unexpected: Resilient performance in an age of uncertainty. 2nd ed. San Francisco: Jossey-Bass. 2007.

[20] Mitchell J. When disaster strikes... The critical incident stress debriefing process. Journal of Emergency Medical Services. 1983; 8: 36-39. PMid: 10258348.

[21] Eurocontrol. Critical Incident Stress Management: User implementation guidelines. Brussels: Eurocontrol. 2008.

[22] Rassin M, Kanti T, Silner D. Chronology of medication errors by nurses: Accumulation of stresses and PTSD symptoms. Issues in Mental Health Nursing. 2005; 26: 873-886. PMid: 16203641. http://dx.doi.org/10.1080/01612840500184566

[23] Scott SD, Hirschinger LE, Cox KR, McCoig M, Brandt J, Hall LW. The natural history of recovery for the healthcare provider “second victim” after adverse patient events. Quality Safety Health Care. 2009; 18: 325-330. PMid: 19812092. http://dx.doi.org/10.1136/qshc.2009.032870

[24] Seys D, Wu AW, Van Gerven E, et al. Health care professionals as second victims after adverse events: A systematic review. Evaluation \& the Health Professions. 2012; 1-28.

[25] Serembus JF, Wolf ZR, Youngblood N. Consequences of fatal medication errors for healthcare providers: A secondary analysis study. MedSurg Nursing. 2001; 10(4): 193-201.

[26] DeVille K. God, science, and history: The cultural origins of medical error. In: Sharpe VA, ed. Accountability: Patient safety and policy reform. Washington, DC: Georgetown University Press. 2004; 143-158.

[27] Paget MA. The unity of mistakes: A phenomenological interpretation of medical work. Philadelphia: Temple University Press. 2004.

[28] Amalberti R, Auroy Y, Berwick D, Barach P. Five system barriers to achieving ultrasafe healthcare. Annals of Internal Medicine. 3 May 2005; 142(9): 756-764. PMid: 15867408. http://dx.doi.org/10.7326/0003-4819-142-9-200505030-00012

[29] McDonald R, Harrison S. The micropolitics of clinical guidelines: An empirical study. Policy and politics. 2004; 32(2): $223-229$. http://dx.doi.org/10.1332/030557304773558161

[30] McDonald R, Waring J, Harrison S. Rules, safety and the narrativization of identity: A hospital operating theatre case study. Sociology of Health \& Illness. 2006; 28(2): 178-202. PMid: 16509952. http://dx.doi.org/10.1111/j.1467-9566.2006.00487.x

[31] Dekker SWA. Patient safety: A human factors approach. Boca Raton, FL: CRC Press. 2011. http://dx.doi.org/10.1201/b10942

[32] Cook RI, Nemeth C, Dekker SWA. What went wrong at the Beatson Oncology Centre? In: Hollnagel E, Nemeth CP, Dekker SWA, eds. Resilience Engineering Perspectives: Remaining sensitive to the possibility of failure. Aldershot, UK: Ashgate Publishing Co. 2008.

[33] Cook RI, Woods DD. Operating at the sharp end: The complexity of human error. In: Bogner MS, ed. Human error in medicine. Hillsdale, NJ: Lawrence Erlbaum Associates. 1994.

[34] Montgomery K. How doctors think: Clinical judgment and the practice of medicine. Oxford, UK: Oxford University Press. 2006.

[35] Dekker SWA. We have Newton on a retainer: Reductionism when we need systems thinking. The Joint Commission Journal on Quality and Patient Safety. 2010; 36(4): 147-149. PMid: 20402369.

[36] Godkin L, Allcorn S. Institutional narcissism, arrogant organization disorder and interruptions in organizational learning. The Learning Organization. 2009; 16(1): 40-57. http://dx.doi.org/10.1108/09696470910927669

[37] Naumann SE, Minsky BD, Sturman MC. The use of the concept 'entitlement' in management literature: A historical review, synthesis, and discussion of compensation policy implications. Human Resource Management Review. 2002; 12: $145-166$. http://dx.doi.org/10.1016/S1053-4822(01)00055-9

[38] Roed-Larsen S, Stoop J, Funnemark E. ESReDA Shaping Public Safety Investigations of Accidents in Europe. Hovik, Norway: Det Norske Veritas. 2005.

[39] Stoop J, Dekker SWA. Are safety investigations proactive? Safety Science. 2012; 50: 1422-1430. http://dx.doi.org/10.1016/j.ssci.2011.03.004

[40] Ferguson J, Fakelmann R. The Culture Factor. Frontiers of Health Services Management. 2005; 22(1): 33-40. PMid: 16223103.

[41] Berwick DM. Improvement, trust, and the healthcare workforce. Qual Saf Health Care. Dec 2003; 12(6): 448-452. PMid: 14645761. http://dx.doi.org/10.1136/qhc.12.6.448

[42] Bosk C. Forgive and remember: Managing medical failure. Chicago, IL: University of Chicago Press. 2003. http://dx.doi.org/10.7208/chicago/9780226924687.001.0001 
[43] Iedema R, Flabouris A, Grant S, Jorm C. Narrativizing errors of care: Critical incident reporting in clinical practice. Social Science \& Medicine. 2006; 62: 134-144. PMid: 15992984. http://dx.doi.org/10.1016/j.socscimed.2005.05.013

[44] Vincent C. Patient Safety. London: Churchill Livingstone. 2006.

[45] Wu AW. Medical error: The second victim. British Medical Journal. 2000; 320(7237): 726-728. http://dx.doi.org/10.1136/bmj.320.7237.726

[46] Ullstrom S, Sachs MA, Hansson J, Ovretveit J, Brommels M. Suffering in silence: a qualitative study of second victims of adverse events. BMJ Quality and Safety. 2013; Nov 15. http://dx.doi.org/10.1136/bmjqs-2013-002035

[47] Edrees HH, Paine LA, Feroli ER, Wu AW. Health care workers as second victims of medical errors. Pol Arch Med Wewn. 2011; 121(4): 101-108. PMid: 21532531.

[48] Mizrahi T. Managing medical mistakes: Ideology, insularity and accountability among internists-in-training. Social Science \& Medicine. 1984; 19(2): 135-146. http://dx.doi.org/10.1016/0277-9536(84)90280-6

[49] Shanafelt TD, Balch CM, Dyrbye L, et al. Suicidal ideation among american surgeons. Arch Surg. 2011; 146(1): 54-62. PMid: 21242446. http://dx.doi.org/10.1001/archsurg.2010.292

[50] Aasland OG, Forde R. Impact of feeling responsible for adverse events on doctors' personal and professional lives: The importance of being open to criticism from colleagues. . Qual Saf Health Care. 2005; 14(1): 13-17. PMid: 15691998. http://dx.doi.org/10.1136/qshc.2002.003657

[51] Christensen JF, Levinson W, Dunn PM. The heart of darkness: The impact of perceived mistakes on physicians. Journal of General Internal Medicine. 1992; 7: 424-431. PMid: 1506949. http://dx.doi.org/10.1007/BF02599161

[52] Cook RI, Nemeth CP. Those found responsible have been sacked: Some observations on the usefulness of error. Cognition, Technology and Work. 2010; 12: 87-93. http://dx.doi.org/10.1007/s10111-010-0149-0

[53] West CP, Huschka MM, Novotny PJ, et al. Association of perceived medical errors with resident distress and empathy: A prospective longitudinal study. JAMA. 2006; 296(9): 1071-1078. PMid: 16954486. http://dx.doi.org/10.1001/jama.296.9.1071

[54] Waterman AD, Garbutt J, Hazel E, et al. The emotional impact of medical errors on practicing physicians in the United States and Canada. The Joint Commission Journal on Quality and Patient Safety. 2007; 33(8): 467-476. PMid: 17724943.

[55] Reason JT. Grace under fire: Compensating for adverse events in cardiothoracic surgery. 5th Conference on Naturalistic Decision Making. Tammsvik, Sweden. 2000.

[56] Engel KG, Rosenthal M, Sutcliffe KM. Residents’ responses to medical error: Coping, learning, and change. . Academic Medicine. 2006; 81(1): 86-93. PMid: 16377827. http://dx.doi.org/10.1097/00001888-200601000-00021

[57] Leape LL. Error in medicine. JAMA. 1994; 272(23): 1851-1857. PMid: 7503827. http://dx.doi.org/10.1001/jama.1994.03520230061039

[58] Lewis HB. Shame and guilt in neurosis. London: International Universities Press. 1971.

[59] Tangney JP. Shame and guilt. New York: Guildford Press. 2002.

[60] Bognár A, Barach P, Johnson JK, et al. Errors and the burden of errors: Attitudes, perceptions, and the culture of safety in pediatric cardiac surgical teams. Ann Thorac Surg. 2008; 85(4): 1374-1381. PMid: 18355531. http://dx.doi.org/10.1016/j.athoracsur.2007.11.024

[61] Newman MC. The emotional impact of mistakes on family physicians. Arch Fam Med. 1996; 5(2): 71-75. PMid: 8601210. http://dx.doi.org/10.1001/archfami.5.2.71

[62] Collins ME, Block SD, Arnold RM, Chistakis NA. On the prospects for a blame-free medical culture. Social Science \& Medicine. 2009; 69(9): 1287-1290. PMid: 19766373. http://dx.doi.org/10.1016/j.socscimed.2009.08.033

[63] Jones JH, Treiber LA. When nurses become the second victim. Nursing Forum. 2012; 47(4): 286-291. PMid: 23127243. http://dx.doi.org/10.1111/j.1744-6198.2012.00284.x

[64] Meurier CE, Vincent CA, Parmar DG. Nurses' responses to severity dependent errors: A study of the causal attributions made by nurses following an error. Journal of Advanced Nursing. 1998; 27: 349-354. PMid: 9515646. http://dx.doi.org/10.1046/j.1365-2648.1998.00512.x

[65] Parker D, Lawton R. Judging the use of clinical protocols by fellow professionals. Soc Sci Med. Sep 2000; 51(5): 669-677. http://dx.doi.org/10.1016/S0277-9536(00)00013-7

[66] Sexton JB, Thomas EJ, Helmreich RL. Error, stress, and teamwork in medicine and aviation: Cross sectional surveys. BMJ. Mar 18 2000; 320(7237): 745-749. PMid: 10720356. http://dx.doi.org/10.1136/bmj.320.7237.745

[67] Pellegrino ED. Prevention of medical error: where professional and organizational ethics meet. In: Sharpe VA, ed. Accountability: patient safety and policy reform. Washington: Georgetown University Press. 2004; 83-98.

[68] Woods DD, Dekker SWA, Cook RI, Johannesen LJ, Sarter NB. Behind human error. Aldershot, UK: Ashgate Publishing Co. 2010.

[69] Conley RJ. Cherokee medicine man: the life and work of a modern-day healer. Norman [Okla.]: University of Oklahoma Press. 2005. 
[70] Mulcahy JB. Birth \& rebirth on an Alaskan island: the life of an Alutiiq healer. Athens, Ga.; London: University of Georgia Press. 2001.

[71] Arvigo R, Epstein N, Yaquinto M. Sastun: My apprenticeship with a Maya healer. 1st ed. San Francisco: HarperSanFrancisco. 1994.

[72] Pilz A. Manang Jabing Anak Incham: a study of an Iban healer/Sarawak. Berlin: D. Reimer. 1988.

[73] Young DE, Ingram G, Swartz L. Cry of the eagle: Encounters with a Cree healer. Toronto; Buffalo: University of Toronto Press. 1989.

[74] Davis-Floyd R, St. John G. From doctor to healer: The transformative journey. New Brunswick, NJ: Rutgers University Press. 1998.

[75] Pellegrino ED, Thomasma DC, Kissell JL. The health care professional as friend and healer: Building on the work of Edmund D. Pellegrino. Washington, D.C.: Georgetown University Press. 2000.

[76] Miles SH. The Hippocratic Oath and the ethics of medicine. Oxford, UK: Oxford University Press. 2004.

[77] Rogers AE, Hwang WT, Scott LD, Aiken LH, Dinges DF. The working hours of hospital staff nurses and patient safety. Health Aff (Millwood). Jul-Aug 2004; 23(4): 202-212. http://dx.doi.org/10.1377/hlthaff.23.4.202

[78] Landrigan CP, Rothschild JM, Cronin JW, et al. Effect of reducing interns' work hours on serious medical errors in intensive care units. N Engl J Med. Oct 28 2004; 351(18): 1838-1848. PMid: 15509817. http://dx.doi.org/10.1056/NEJMoa041406

[79] Welch DL. Human factors usability test and evaluation. Biomed Instrum Technol. Mar-Apr 1998; 32(2): 183-187. PMid: 9559116.

[80] Yentis S. Of humans, factors, failings and fixations. Anaesthesia. 2010; 65(1): 1-4. PMid: 20121771. http://dx.doi.org/10.1111/j.1365-2044.2009.06018.x

[81] Cacciabue PC, Vella G. Human factors engineering in healthcare systems: The problem of human error and accident management. International Journal of Medical Informatics. 2010; 79(4): 1-17. PMid: 19101197. http://dx.doi.org/10.1016/j.ijmedinf.2008.10.005

[82] Wears RL, Perry SJ. Human factors and ergonomics in the emergency department. Ann Emerg Med. Aug 2002; 40(2): $206-212$. PMid: 12140500. http://dx.doi.org/10.1067/mem.2002.124900

[83] Dunn E, Wolfe J. What's not wrong with this prescription? Drug Topics. 2002; 146(9): 25-26.

[84] Peterson GM, Wu MSH, Bergin JK. Pharmacists' attitudes towards dispensing errors: Their causes and prevention. Journal of Clinical Pharmacy \& Therapeutics. 1999; 24(1): 57-71. http://dx.doi.org/10.1046/j.1365-2710.1999.00199.x

[85] Leonhardt J, Vogt J. Critical incident stress management in aviation. Aldershot, UK: Ashgate Publishing Co.; 2006.

[86] Eurocontrol. Critical Incident Stress Management: Human factors module. Brussels: Eurocontrol: European Organization for the Safety of Air Navigation. 1997.

[87] Reason JT. Managing the risks of organizational accidents. Aldershot, UK: Ashgate Publishing Co. 1997.

[88] Denham CR. TRUST: The 5 rights of the second victim. Journal of Patient Safety, 2007; 3: 107-119. http://dx.doi.org/10.1097/01.jps.0000236917.02321.fd

[89] Dekker SWA. Second victim - error, guilt, trauma and resilience. Australia: CRC Press; 2013. http://dx.doi.org/10.1201/b14797

[90] McDonald TB, Helmchen LA, Smith KM, et al. Responding to patient safety incidents: The seven pillars. Qual Saf Health Care. 2010; 19(e11). 